\title{
C-Met Inhibitor
}

National Cancer Institute

\section{Source}

National Cancer Institute. c-Met Inhibitor. NCI Thesaurus. Code C143099.

Any small molecule that inhibits the enzymatic activity of the receptor tyrosine kinase cMet (hepatocyte growth factor receptor; HGFR). 